\title{
Uncommon involvement of multiple lesions in the oral cavity: A case report
}

\author{
Envolvimento incomum de lesões múltiplas na cavidade oral: Relato de caso \\ Afectación infrecuente de múltiples lesiones en la cavidad oral: Reporte de un caso
}

Received: 05/09/2021 | Reviewed: 05/13/2021 | Accept: 05/15/2021 | Published: 05/30/2021

\author{
Thiago Vasconcelos Melo \\ ORCID: https://orcid.org/0000-0002-9925-7644 \\ Federal University of Ceará, Brazil \\ Email: thiagovascm@gmail.com \\ Jefferson Douglas Lima Fernandes \\ ORCID: https://orcid.org/0000-0002-5231-3813 \\ Federal University of Ceará, Brazil \\ Email: jefferson.odonto97@gmail.com \\ Denise Hélen Imaculada Pereira Oliveira \\ ORCID: https://orcid.org/0000-0001-6020-2374 \\ Federal University of Ceará, Brazil \\ Email: denise.oliveira@ sobral.ufc.br \\ Marcelo Bonifácio da Silva Sampieri \\ ORCID: https://orcid.org/0000-0001-7942-6642 \\ Federal University of Ceará, Brazil \\ Email: mar_sampieri@hotmail.com \\ Fábio Wildson Gurgel Costa \\ ORCID: https://orcid.org/0000-0002-3262-3347 \\ Federal University of Ceará, Brazil \\ Email: fwildson@yahoo.com.br \\ Francisco Samuel Rodrigues Carvalho \\ ORCID: https://orcid.org/0000-0002-3142-1268 \\ Federal University of Ceará, Brazil \\ Karuza Maria Alves Pereira \\ ORCID: https://orcid.org/0000-0002-2880-6466 \\ Federal University of Ceará, Brazil \\ Email: karuzaalves@yahoo.com.br \\ Filipe Nobre Chaves \\ ORCID: https://orcid.org/0000-0001-6345-8156 \\ Federal University of Ceará, Brazil \\ Email: filipenobrechaves@gmail.com
}

\begin{abstract}
In maxillomandibular complex lesions of various etiolopathogenesis may occur. Commonly, lesions are solitary, however, in in rare cases, multiple lesions with distinct natures affect the maxillo-mandibular complex. Until now, the recent literature, there are no reports of simultaneous impairment of periapical cysts, dentigerous and cementoblastoma in the same patient. We report the case of a 38-year-old with syndromic appearance, short stature, brachyfacial, showing hypertelorism, but no definitive diagnosis with multiple oral lesions in the jaws. In the reported case, a residual periapical cyst associated with the swelling in the anterior region of the maxilla occurring simultaneously to a dentigerous cyst and associated with tooth 35 cementoblastoma included. Despite the simultaneous involvement of multiple lesions with different etiopathogenesis is uncommon in the literature, this report seeks to emphasize the importance of thorough and systematic clinical examination, promoting proper conduct of maxillary lesions and perform the correct treatment.
\end{abstract}

Keywords: Dentigerous cyst; Radicular cyst; Odontogenic cyst; Tooth, unerupted; Odontogenic tumors.

\section{Resumo}

No complexo buco-maxilo-mandibular, podem ocorrer lesões de distintas etiopatogenias. Comumente, as lesões são solitárias, porém, em casos raros, lesões múltiplas de naturezas distintas ocorrem nos maxilares. Até o momento, na literatura recente, não há relatos de comprometimento simultâneo de cistos periapicais, dentígeros e cementoblastoma no mesmo paciente. Relatamos o caso de uma paciente de 38 anos com aspecto sindrômico, baixa estatura, braquifacial, apresentando hipertelorismo, mas sem diagnóstico definitivo com múltiplas lesões orais nos maxilares. No caso relatado, um cisto periapical residual associado ao edema na região anterior da maxila ocorrendo simultaneamente a um cisto dentígero e associado ao dente 35 , cementoblastoma incluído. Apesar do envolvimento simultâneo de múltiplas lesões com diferentes etiopatogenias ser incomum na literatura, este relato busca enfatizar a 
importância do exame clínico minucioso e sistemático, promovendo a conduta adequada das lesões maxilares e realizando o tratamento correto.

Palavras-chave: Cisto dentígero; Cisto radicular; Cistos odontogênicos; Dente não erupcionado; Tumores odontogênicos.

\section{Resumen}

No complexo buco-maxilo-mandibular, podem ocorrer lesões de distintas etiopatogenias. Comumente, as lesões são solitárias, porém, em cases raros, lesões múltiplas de naturezas distintas ocorrem nos maxilares. Até o momento, na literatura recente, não há relatos de comprometimento simultâneo de cistos periapicais, dentígeros e cementoblastoma no mesmo paciente. Relatamos o caso de uma paciente de 38 anos com aspecto sindrômico, baixa estatura, braquifacial, apresentando hipertelorismo, mas sem diagnóstico definitivo com múltiplas lesões orais nos maxilares. No caso relatado, um cisto periapical residual associado ao edema na região anterior da maxila ocorrendo simultaneamente a um cisto dentígero e associado ao dente 35, cementoblastoma incluído. Apesar do envolvimento simultâneo de múltiplas lesões com diferentes etiopatogenias ser incomum na literatura, este relato busca enfatizar a importância do exame clínico minucioso e sistemático, promovendo una conduta adequada das lesões maxilares e realizando o tratamento correto.

Palabras clave: Quiste dentígero; Quiste radicular; Quistes odontogénicos; Diente no erupcionado; Tumores odontogénicos.

\section{Introduction}

The maxillomandibular complex is home to several lesions, usually solitary, such as odontogenic cysts and tumors. Jaw cysts are considered uncommon in clinical practice, although they constitute a large percentage of specimens in oral and maxillofacial pathology practice. Jaw cysts are classified as true cysts or pseudocysts, depending on the presence or absence of lining epithelium; as inflammatory or developmental based on their pathogenesis, and odontogenic or non-odontogenic according to the tissue of origin (Tamiolakis et al., 2019).

Odontogenic cysts, such as the dentigerous cyst and the residual cyst, originate in remnants of the dental lamina or enamel organ but have different etiological factors (Khosravi et al., 2013; Johnson et al., 2014; Kammer et al., 2020). In contrast, cementoblastoma is a relatively rare odontogenic neoplasm of the jaws. It is characterized as a large mass of cementum or cementum-like tissue that is attached to the roots of a tooth (Garg et al., 2019).

However, despite the importance of these lesions, with few examples in the literature, the simultaneous occurrence in the same patient is uncommon. To presently, there are no reports in the literature of the simultaneous occurrence of periapical, dentigerous, and cementoblastoma cyst in the same patient.

Thus, the present study aims to report an unusual simultaneous occurrence of a residual cyst associated with the mandibular tooth 35 included dentigerous cyst and cementoblastoma in the same patient.

\section{Methodology}

This article is a clinical case report with a qualitative and descriptive approach. According to Estrela et al. (2018), such research is seen as research in which direct data collection occurs, with the researcher being the main means. This study has the patient's permission through the Informed Consent Term (ICF) of the stomatology sector of the Federal University of Ceará - Campus Sobral, elaborated in language accessible to the understanding of the reported patient, evidencing the destination of the information collected from the patient, as well as the associated risks and benefits.

\section{Case Report}

37-years old, woman, edentulous, reporting pain in the upper jaw. In the oral examination, anterior maxillary swelling was observed with a mucosa-like color, soft consistency, and smooth surface, and asymptomatic (Fig. 1). Clinically, 
the patients presented multiple oral lesions in the jaws, associated a short stature, brachyfacial, showing hypertelorism or syndrome aspects, however without a definitive diagnosis.

Figure 1. Extra-oral examination (A) and oroscopy without significant alterations. Mention for absence of swelling or tooth displacement (B, C, D).

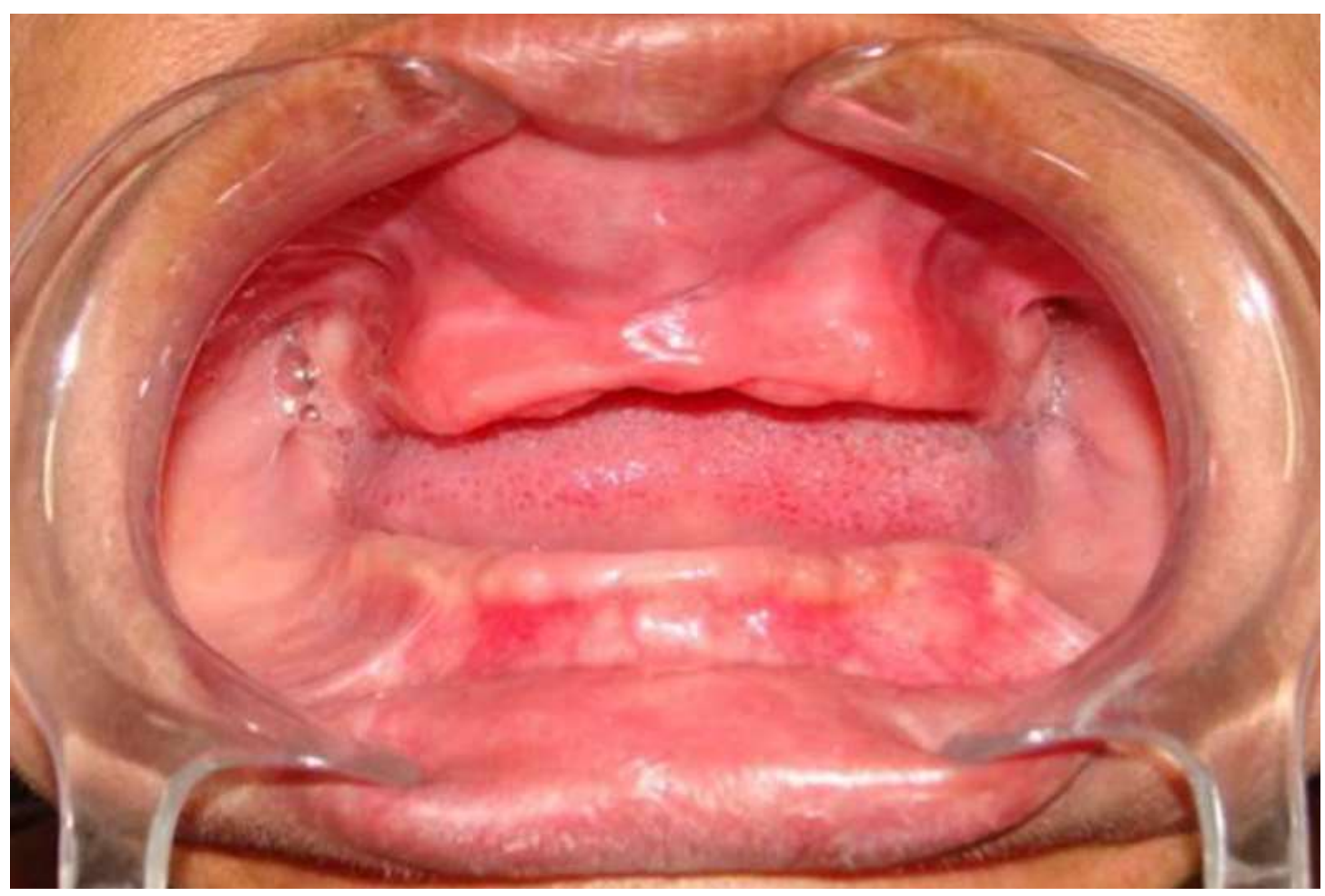

Source: Authors.

The panoramic radiography showed an maxillary anterior unilocular circumscribed radiolucent area with significant anteroposterior growth (Fig. 2A). Panoramic radiography showed a well-defined radiolucent area in the coronary portion of mesioangular and included tooth 35 , associated a radiopaque lesion circumscribed by a radiolucent halo in the periapical region (Fig. 2B).

Figure 2. Panoramic radiography showing a unilocular radiolucent image in the anterior maxillary region and teeth 35 impacted (A). Periapical radiograph showing embedded in the bone tooth 35 with a radiolucent lesion associated with a dental crown and a periapical radiopaque lesion surrounded by a radiolucent halo (B).
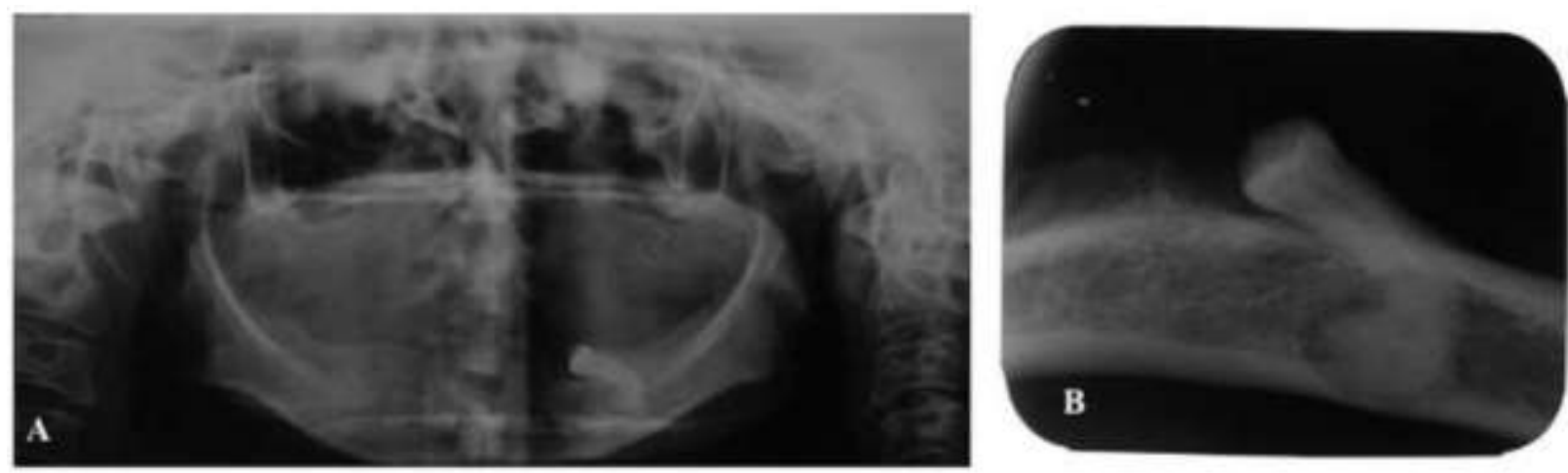

Source: Authors. 
The diagnostic hypothesis of the maxillary lesion was a residual periapical cyst and the mandibular lesions were dentigerous cyst and cementoblastoma. Excision biopsies were performed at different surgical times. Histopathologically, the maxillary lesion had a pathological cavity partially covered by squamous oral epithelium, sometimes cubic, under which there is a capsule of dense fibrous connective tissue (Fig. 3A), with a diagnosis of an inflammatory periapical cyst. In mandibular lesions, for lesion associated with the coronary portion, revealed a cystic cavity covered by stratified non-keratinized squamous epithelium, showing areas of epithelial projections and exocytosis (Fig. 3B), with a diagnosis of a dentigerous cyst. The apical lesion of tooth 35, on the other hand, had a histopathological diagnosis of cementoblastoma, a benign neoplasm composed of mineralized tissue compatible with cementum (Fig. 3C). The patient has been followed for 5 years, without recurrence of the lesions.

Figure 3. Photomicrograph shows a cystic wall surrounded by dense connective tissue, revealing hemorrhagic areas and foci of inflammatory infiltrate (HE; 200X) (A). The presence of a non-keratinized epithelial lining is verified, presenting projections and exocytosis, with a fibrous capsule showing lymphoplasmacytic inflammatory infiltrate (HE; 100X) (B). Mineralized tissue is observed, compatible with dentin and cement (HE; 200X) (C).
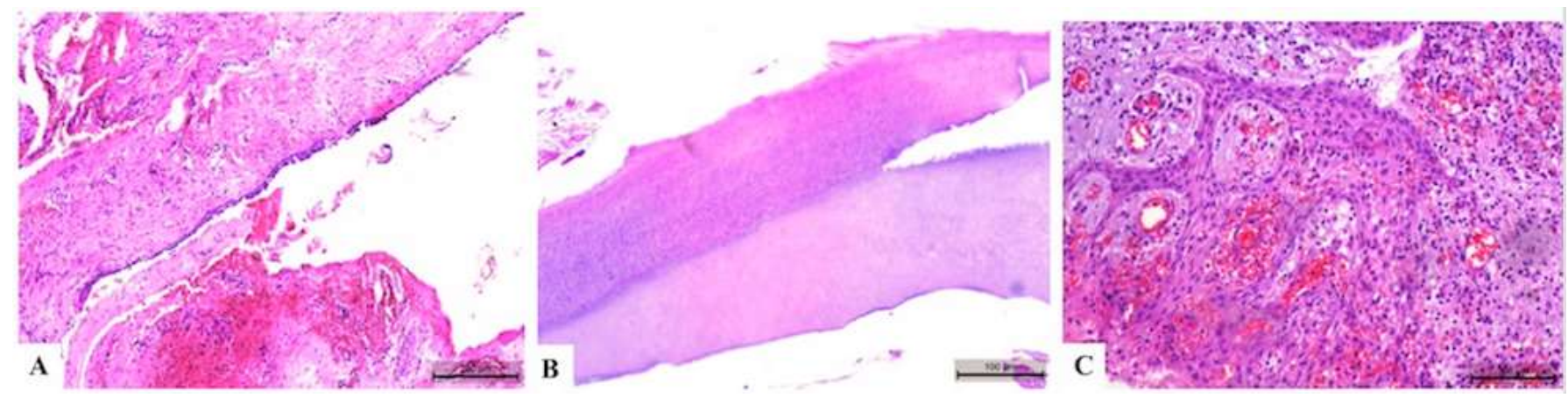

Source: Authors.

\section{Discussion}

Using Pubmed data we have so far, there are no reports of the coexistence of dentigerous and residual cysts and cementoblastoma carcinoma. We believe that such coexistence must not have the same etiology, but rather a very particular one. Thus, our approach followed the guidelines of each lesion, respecting their biological behaviors. Odontogenic cysts are intraosseous pathological cavities lined by odontogenic epithelium and filled with liquid or semi-liquid content inside, often detected by radiographic exams for other purposes (Pereira et al., 2010; Khosravi et al., 2013; Speight et al., 2018). Odontogenic cysts have a prevalence of $1.3 \%$ in the maxillofacial complex including up to $90 \%$ of mandibular cysts and can be classified according to the World Health Organization (WHO), as developmental cysts and inflammatory cysts (Mohajerani et al., 2015; Kammer et al., 2020), the latter being the which has a higher incidence in the population. The dentigerous cyst is the most common developmental odontogenic cyst, covering $11.4 \%$ to $35.5 \%$ of all odontogenic cysts (Johnson et al., 2014; Mohajerani et al., 2015), however inflammatory odontogenic cysts are more frequent (Johnson et al., 2014). The residual periapical cyst is a type of inflammatory cyst that remains after tooth extraction associated with inadequate curettage. Root cysts represent $54.26 \%$ of all odontogenic cysts, followed by dentigerous cysts, $22.94 \%$, and residual cysts, $7.21 \%$, which may vary according to the population studied (Johnson et al., 2014; Mohajerani et al., 2015).

Odontogenic tumors include around $0.6 \%$ of all lesions that affect the maxillofacial region, with Cementoblastoma being associated with $0.8 \%$ to $2.6 \%$ of all these tumors, which makes it a relatively uncommon pathology (Pereira et al., 2010; Wright et al., 2017; Speight et al., 2018). Cementoblastoma originates from the ectomesenchyme odontogenic, usually found 
in young patients, characterized by the proliferation of tissue similar to cementum in juxtaposition with the tooth roots (Nogueira et al., 2014; Prakash et al., 2014; Çalışkan et al., 2016), which differentiates them from osteoblastoma, but when Osteoblastoma of the jaws when is associated with the roots of teeth, it is difficult to distinguish from cementoblastoma (Manjunatha et al., 2011). This tumor is commonly found in solitary form and usually develops along with the roots of permanent teeth, in rare cases that occur associated with the tooth completely encased in bone embedded teeth.

Although benign lesions, the development of odontogenic cysts and tumoral lesions may be associated with significant bone resorption, damage to dental structures, and adjacent anatomical structures such as the maxillary sinus, nasal cavity, and mandibular fractures, especially when they reach large proportions, justifying the intervention surgical (Aoki et al., 2018; Kammer et al., 2020; Santosh et al., 2020). Benign cementoblastoma has unlimited growth potential. Hence, the preferred treatment is complete surgical excision along with the extraction of the associated tooth (Hiremath et al., 2020). Dentigerous and residual cysts growths can promote bone resorption, causing bone defects, which impairs the patient's functional rehabilitation, in addition to major swelling leading to loss of prosthesis stability, as reported in the finding s of this case.

We emphasize the importance of routine radiographic examinations in dental practice for a correct diagnosis of intraosseous injuries of the jaws, to minimize the risk of complications related to late diagnosis. It is known that panoramic radiography is a useful aid for diagnoses, but it only shows two-dimensional images of three-dimensional structures. In addition, it has a limited value to determine the lesion size and margins tissue composition, as well as bone destruction and expansion patterns (Martinelli-kläy et al., 2019), therefore it must be associated with other exams. As the concomitant presentation of these lesions does not have the same etiology, despite their particular appearance, the approach followed the most suitable treatments for each lesion, respecting their biological behavior. With regard to these lesions, such as the dentigerous cyst, it is essential to perform a histopathological exam for the differential diagnosis, discarding the other types of injuries with similar clinical-radiographic characteristics, in addition to annual postoperative radiographic follow-up (Caliento et al., 2016).

\section{Conclusion}

Oral lesions can be associated with a wide range of etiological factors, including infection, immune dysregulation, trauma, and neoplasms. Although careful medical history and clinical evaluation can lead to a presumptive clinical diagnosis in many cases, biopsy and imaging exams and /or additional adjuvant tests may be necessary to confirm the diagnosis or rule out a neoplastic origin. To date, there are no case reports that present a combination of the residual periapical cyst, dentigerous cyst, and cementoblastoma in the same patient, which is believed to be an unusual case. Despite the rarity of the present case, the importance of a meticulous clinical examination is emphasized, even in edentulous patients, so that the correct diagnosis can be reached, leading to adequate management in the face of multiple maxillomandibular lesions.

\section{Acknowledgments}

The authors would like to thank Profa. Dra. Ana Paula Negreiros Nunes Alves and Prof. Dr. Mário Rogério Lima Mota from the Laboratory of Oral Pathology of the Federal University of Ceará, Brazil, for the contribution in physical structure of his Laboratory.

\section{References}

Aoki, N., et al. (2018). Multidisciplinary approach for treatment of a dentigerous cyst - marsupialization, orthodontic treatment, and implant placement: a case report. Journal of medical case reports, 12(1), 305. 
Research, Society and Development, v. 10, n. 6, e28710615911, 2021

(CC BY 4.0) | ISSN 2525-3409 | DOI: http://dx.doi.org/10.33448/rsd-v10i6.15911

Caliento, R., et al. (2013). Dentigerous cyst: modalities of treatment. Revista de Odontologia da UNESP, 42(6), 458-462.

Çalışkan, A., et al. (2016). Benign cementoblastoma of the anterior mandible: an unusual case report. Journal of the Korean Association of Oral and Maxillofacial Surgeons, 42(4), 231-235.

Estrela, C. (2018). Scientific Methodology: Science, Teaching, Research. Editora Artes Médicas.

Garg, B., et al. (2019). Cementoblastoma associated with the primary second molar: An unusual case report. Journal of oral and maxillofacial pathology : JOMFP, 23(Suppl 1), 111-114.

Hiremath, M. C., et al. (2020). Benign cementoblastoma associated with primary mandibular second molar: A rare case report. Journal of oral and maxillofacial pathology: JOMFP, 24(Suppl 1), S11-S14.

Johnson, N. R., et al. (2014). Frequency of odontogenic cysts and tumors: a systematic review. Journal of investigative and clinical dentistry, 5(1), 9-14.

Kammer, P. V., et al. (2020). Comparative analysis between developmental and inflammatory odontogenic cysts: retrospective study and literature review. Oral and maxillofacial surgery, 24(1), 73-84.

Khosravi, N., Razavi, S. M., Kowkabi, M., et al. (2013). Demographic distribution of odontogenic cysts in Isfahan (Iran) over a 23-year period (1988-2010). Dent Res J (Isfahan), 10:162-7.

Manjunatha, B. S., et al. (2011). Osteoblastoma of the jaws: report of a case and review of literature. Clinics and practice, 1(4), e118.

Martinelli-Kläy, C. P., et al. (2019). Unusual Imaging Features of Dentigerous Cyst: A Case Report. Dentistry journal, 7(3), 76.

Mohajerani, H., et al. (2015). Diagnostic Factors of Odontogenic Cysts in Iranian Population: A Retrospective Study Over the Past Two Decades. Iranian Red Crescent medical journal, 17(6), e21793.

Nogueira, A. S., et al. (2014). Simultaneous occurrence of dentigerous cyst and residual cyst in the maxilla. Brazilian Journal of Otorhinolaryngology, 80(1), 88-89.

Pereira, J. V., et al. (2010). Prevalência de cistos e tumores odontogênicos em pacientes atendidos na Fundação Assistencial da Paraíba: estudo retrospectivo. Arquivos em Odontologia, 46(2), 75-81.

Prakash, R., et al. (2014). Cementoblastoma: A report of three new cases. Indian Journal of Dentistry, 5(1), 54-57.

Santosh, A. B. R. (2020). Odontogenic Cysts. Dental Clinics, 64(1), 105-119.

Sharma, N. (2014). Benign cementoblastoma: a rare case report with review of literature. Contemporary clinical dentistry, 5(1), 92.

Speight, P. M., \& Takata, T. (2018). New tumour entities in the 4th edition of the World Health Organization Classification of Head and Neck tumours: odontogenic and maxillofacial bone tumours. Virchows Archiv : an international journal of pathology, 472(3), 331-339.

Tamiolakis, P., et al. (2019). Demographic and Clinical Characteristics of 5294 Jaw Cysts: A Retrospective Study of 38 Years. Head and neck pathology, 13(4), 587-596. https://doi.org/10.1007/s12105-019-01011-7

Wright, J. M., \& Soluk Tekkesin, M. (2017). Odontogenic tumors: where are we in 2017 ?. Journal of Istanbul University Faculty of Dentistry, 51(3 Suppl 1), S10-S30. 